\title{
The Oostvaardersplassen:
}

\section{'Making Space' (for) Wilderness}

\author{
Eline Smeets
}

I desire to speak somewhere without bounds; like a man in a waking moment, to men in their waking moments; for I am convinced that I cannot exaggerate enough even to lay the foundation of a true expression. - Thoreau Walden

\section{Introduction}

Dutch conservationist Thomas van Slobbe claims to have created real wilderness outside the human order by placing a hedge around a small piece of land in an unknown nature reserve somewhere in the Netherlands. Out of sight and out of mind, this place cannot be experienced, valued or made subject to human plans (2005). He presents this event in a fictional story about the perfect crime: Expropriating a piece of land from humankind, from the right to own, to allocate and to experience. His story is a response to the deconstruction of the received wilderness idea, an understanding of wilderness as pristine and untrammeled by man. This on-going deconstruction has not yet reached a conclusion, and thus all of our current interactions with nature, including the Oostvaardersplassen project, the site of this study, are part of it.

A relatively new idea, which we see in the Netherlands from 1980 onwards, is that of creating 'new wilderness'. In these new wildernesses experts establish some basic conditions and guidelines as well as constraints after which a more 'hands-off approach' to conservation is adopted and nature is given the space and freedom to develop autonomously (Wolf, 2012, pp.16-17). The Oostvaardersplassen is an example of one such place. Its intellectual founder, the Dutch ecologist Frans Vera, is one of a number of experts interested in the possibilities creating new wilderness, a practice also known as 'rewilding', offers. Simply letting nature take control of the landscape and allowing ancient ecosystems to reassert themselves, they believe, can reverse thousands of years of domestication (BBC, 2013). Considered one of the most ambitious rewilding projects in Europe, the Oostvaardersplassen, however, remains controversial. The controversy seems to be centered on the welfare of the large grazers in the reserve, many of which are culled or die naturally from starvation, as this relatively small nature reserve does not provide 
enough food for all animals to endure winter. What becomes clear if you read between the lines, however, is that this debate, which seems to be about animal welfare, is actually concerned with the practical implications of creating new wilderness, a kind of nature which is artificial and hyper-natural at the same time and demands a paradigm shift in our thinking about wilderness.

This study aims at providing greater insight into the ongoing controversy around this particular nature reserve, from a humanities and social sciences perspective. It will do so by analysing what role experts play in establishing and maintaining the Oostvaardersplassen as new wilderness, both physically as well as mentally. The Oostvaardersplassen provide an interesting case study, as this area quite literally does not have a history as it is situated about five meters below sea level. Experts had to not only establish physical wilderness here, but also make people understand the product of their labor as such; real wilderness worth conserving. As a consequence, every violation of this understanding can make the reserve meaningless. The concept of scripted space will help decode this coded landscape and elucidate the way in which experts tell the story of the Oostvaardersplassen, and to what extent their story lines up with their actions. It will also help develop an alternative understanding of the reasons behind the controversy, or at least deepen our current understanding of it.

This study will add to the ongoing deconstruction of the concept of wilderness. The relatively new approach to nature conservation or nature development rather, referred to as rewilding, offers a challenge to the received idea of wilderness as pristine and untrammeled. Besides offering another perspective in a global debate on, or deconstruction of, the concept of wilderness, this study follows in a line of fairly recent studies on the meaning of wilderness (in the Netherlands). These studies have focused on which kind of nature we wish to preserve in the Netherlands and why, as well as the role nature conservation organizations play in developing new visions on conservation (van der Windt, 1995). Others have highlighted the experience of natural landscapes in the Netherlands by different groups of people, as Agnes van den Berg describes in Individual Differences in the Aesthetic Evaluation of Natural Landscapes (1999). In Grenzen aan Wildheid (2003), finally, Martin Drenthen addressed the moral meaning of nature and its relation to and implications for human beings. This study is original as it focuses specifically on new wilderness and its relation to the deconstruction of the received wilderness idea. It is particularly relevant, as it pays special attention to the narratives used to establish a new wilderness as holding the same merits as pristine wilderness and the possible consequences of such a move.

After explaining the methodology of this study, an overview of the changing conception 
of wilderness will be given to help understand what problems as well as opportunities, establishing the Oostvaardersplassen as new wilderness, a very particular type of nature, offers. This overview will also include a summary of the most recent changes in thinking about nature conversation in the Netherlands in particular, and concludes with a description of rewilding. The history of the Oostvaardersplassen project will provide the necessary information to be able to compare the physical establishment of new wilderness by the experts with the mental one, later in the study. In order to do so, the history of the concept of scripted space, as well as its application in this particular study, will be introduced in the next part. The analysis will follow and lead up to the conclusion in which the main findings will be summarized and discussed.

\section{Methodology}

This thesis draws predominantly on qualitative methodologies as it aims to understand the role experts played in establishing and maintaining the Oostvaardersplassen as new wilderness, both physically as well as mentally, in order to deepen our understanding of the controversy surrounding the Oostvaardersplassen. It will do so by comparing the way experts physically established and maintained the Oostvaardersplassen as wilderness with the way they have narrated the project as well as their role in it.

Experts, in this study, are considered to be those people who have influenced the establishment and maintenance of the area in some way or another, because they actually had a say in the process. In general, these are the people who came up with the idea to turn this previously empty piece of land into a new wilderness, the people associated with Staatsbosbeheer, which owns the reserve and is in charge of the maintenance of it, and people associated with the rewilding movement.

A thorough literature review will help outline the main issues and debates concerning (the deconstruction of) wilderness and rewilding in general and the Oostvaardersplassen in particular. The concept of scripted space provides a way of separating the physical from the mental establishment and maintenance of wilderness and will prove beneficial in decoding the Oostvaardersplassen to discover how the reserve works as wilderness. The analysis will make use of De Nieuwe Wilderness (2013), the feature-length film about the reserve, the educational materials published in the aftermath of the film as well as press releases by Staatsbosbeheer and texts on rewilding that mention the Oostvaardersplassen.

A possible shortcoming of using this concept in the analysis is that it may prove to be less suited for analyses of the coding of a landscape, which is at least partly natural. Furthermore, although more than enough material was generated for the purpose of scripting the Oostvaardersplassen, a possible limitation of the sources is the similarity 
of most of the material produced by Staatsbosbeheer as the film, the book as well as the educational material largely draw on the same story.

This limitation was one of the main motivations for conducting some interviews with experts to generate extra empirical data. Another part of the research thus involved carrying out three semi-structured interviews with experts associated with the Oostvaardersplassen, namely environmental philosopher Martin Drenthen, ecologist and founder of the Oostvaardersplassen Frans Vera, and nature developer and one of the founders of Rewilding Europe Wouter Helmer. These three hour-long interviews were conducted separately in order to avoid the experts influencing one another's opinion. Besides that, they were not made aware, until after the interview, who the other experts were. The interviewees were questioned about their conception of wilderness, the opinion on the Oostvaardersplassen project as wilderness, the controversy surrounding the project, as well as possible solutions. The interviews were recorded and transcribed and subsequently approved by the experts themselves before they were used in the analysis.

The following paragraphs will give an overview of the origin of the concept of wilderness as well as the changing understanding of the concept, and includes a summary of the most recent changes in thinking about nature conservation in the Netherlands in particular. It concludes with a description of rewilding to provide a context for the Oostvaardersplassen project.

\section{'Wilderness'}

Wilderness and the American Mind (1967), a classic, but slightly older text by wilderness historian Roderick Nash will help track the changing attitude concerning nature. The essay The Trouble with Wilderness, or, Getting Back to the Wrong Nature (1995), by environmental historian William Cronon, besides also tracing the development of this problematic concept, in addition criticizes not wilderness itself, but certain things we believe as a result of the complex cultural construction of wilderness. His work will help illustrate how our way of understanding this specific type of nature undermines true preservation.

First, it is important to understand that to some people, wilderness has no meaning for nomadic hunters and gatherers, for example, or Indians who were removed from the site they once called home to create 'uninhabited wilderness', in order to answer to the myth of wilderness as untrammeled land. These people understood themselves as part of a seamless living community, and thus, the concept of wilderness did not resonate with them. What this also shows is that wilderness is a human creation, a cultural product. Or as Martin Drenthen puts it: "Our concepts and images of nature are the result of processes of interpretation, in which all sorts of cultural and historical influences play a part" (2005, p.318). 
With the advent of herding and agriculture and human settlement, the first lines are drawn between that which is controlled and that which is not; lines that turned out to be pivotal in understanding ourselves as different from, and better than nature (Nash, 2001, pp.xi-xii). Up until the eighteenth century, wilderness carried mostly negative connotations. It was considered waste in the sense that it was uncultivated. In a biblical context, wilderness referred to "a place to which one came only against one's will, and always in fear and trembling” (Callicott \& Nelson, 1998, p.473). And so a split was created, dividing (uncontrolled) nature from culture; and as a consequence "the largest portion of the energy of early civilization was directed at conquering wildness in nature and eliminating it in human nature" (Nash, 2001, p.xii). Nature, once our habitat, lost its meaning as something to which humans belonged and became a foe, an opponent to keep out, to fight, and to use or even take advantage of. This is how nature became wilderness.

By the end of the nineteenth century, however, both the cultural construct of the sublime as well as the myth of the frontier transformed wilderness, once considered waste, into something deemed priceless. A gradual transformation in thought replaced old pastoral biases with an appreciation of wilderness as the concept became loaded with "some of the deepest core values of the culture that created and idealized it" (Callicott \& Nelson, 1998, p.475). The doctrine of the sublime, an expression of romanticism, considered wilderness a place where one could have the experience of feeling insignificant. These especially powerful landscapes like dark forests, high mountains, and waterfalls offered an experience analogous to a direct face-to-face encounter with God. At first considered overwhelming, intimidating and terrifying even, the fear of the sublime began to subside. By the second half of the nineteenth century, wilderness was tamed and its inhuman beauty was celebrated (Callicott \& Nelson, 1998, pp.475-477). A transformation in thought had turned wilderness into something to appreciate and revel in.

The myth of the frontier, an idealization of the frontier as a place where human beings could "shed the trappings of civilization" (ibid., p.479) and rediscover their primitive vigour, creativity and independence, turned wilderness into something worth looking after. The sentiment concerning the frontier, and the idea that it was passing away, turned modernity and all it represented into the enemy. Modern life was deemed confining, false and artificial. "Some even began to reason that since the wilderness had been conquered; now it was time to conquer the self-destructive tendencies of civilization. Wilderness might be useful in this task as a symbol of restraint, an environmental base on which to build a legacy of limitation and sustainability" (Nash, 2001, p.xiv). Only by the end of the twentieth century is wilderness considered something that has the right to exist 
independent of what it can offer us.

The concept of wilderness, created in the context of fear and opposition, has undergone a transformation, which is still incomplete. This fairly recent and quite profound change has revealed that wilderness is entirely a creation of the culture that holds it dear, as well as a reflection of the civilization - and a product of the history - it seeks to deny. Wilderness, the ultimate landscape of authenticity, "embodies a dualistic vision in which the human is entirely outside the natural" (Callicott \& Nelson, 1998, p.484). This is what Cronon, considers the trouble with wilderness, as it reproduces those values its admirers seek to deny. Our very presence in wilderness will reduce it to mere tamed and domesticated nature. Or in other words: where we are, nature is not. The received wilderness idea has no room for us. As long as we reproduce this dualism, humanity as the opposite of nature, we will never rediscover our place in it. Humans will never again understand nature as their habitat, and will also miss out on understanding themselves as natural.

\section{Wilderness in the Netherlands}

In order to situate the Oostvaardersplassen project, the next paragraphs deal with the development in thinking about nature conservation in the Netherlands from 1980 onward.

The roots of the changes that took place after 1980 are a development in ecological thinking. Nature management and nature conservation see a strong development in the twentieth-century through the efforts of organisations like Natuurmonumenten' and Staatsbosbeheer ${ }^{2}$. There is, however, an on-going discussion about the level and method of management necessary for successful nature conservation (Wolf, 2012, p.100). In the forties and fifties, nature conservation in the Netherlands focused mainly on conserving existing 'half- or semi-natural areas, those landscapes in which flora and fauna settled spontaneously, but was then managed by human beings. Preservation of these areas asked for active maintenance (p.10o). There were also some areas in which nature was more or less free to run its own course (Gorter, 1986, p.192). In the eighties however, experts observed a decline in biodiversity in especially these types of areas. Human interference in the surrounding landscape was seen as one of the major factors in this. In the following years, biodiversity kept decreasing, even in intensively monitored and managed nature

1 Society for preservation of nature monuments in the Netherlands, founded in 1905 by Jac. P. Thijsse, which buys, protects and manages nature reserves in the Netherlands. Current owner of the Oostvaardersplassen.

2 Staatsbosbeheer is commissioned by the Dutch government and manages a sizeable amount of the nature reserves in the Netherlands. 
areas. This awareness caused experts to seriously reconsider their beliefs and methods (Wolf, 2012, p.100).

It was the spontaneous development in the Oostvaardersplassen, and the fact that the area did not become overgrown as a result of a lack of management, which caused a change in thinking (p.101; Vera, 1979). This gave rise to a belief in large-scale nature reserves with enough space for natural processes, supported by the Theory of Island Biogeography by MacArthur \& Wilson (1967). Dutch nature reserves were now considered too small as it became clear that, like islands, they were surrounded by agriculture and industry or cities limiting the exchange with other reserves. People started to understand that biodiversity could be maintained by creating large-scale nature reserves, rather than protecting small historico-cultural landscapes in which the type of preferred nature was derived from agriculture. This gave rise to the idea of, besides still protecting existing nature reserves, seeing if it was possible to create new and larger nature areas (Wolf, 2012, p.101).

The belief in what we have come to know as nature development, gave rise to another concept which emphasizes the action in its name which will be discussed in the next paragraph.

\section{Rewilding}

In the second half of the $20^{\text {th }}$ century, questions began to emerge about the then dominant approach to nature conservation in Europe. Focussing on protecting the last patches of wilderness, no longer seemed enough, "ours will be an age of rewilding” (Mackinnon, 2013, p.135). From now on, conservationists would focus on the potential of nature, its capacity to sustain abundance even in our presence. The term rewilding thus accounts for those conservation practices focussed on bringing back certain flora and fauna, and with that those ecological processes that allow nature to express its full potential.

The main feature of rewilding is that it creates space for natural processes or wildness. Rewilding is based on a belief in forms of nature conservation in which nature itself is used as a source of inspiration rather than preconceived ideas people may have about nature or wilderness and what it is supposed to look and/or act like (Helmer, personal communication, June 3, 2014). Ecologist and one of the founders of Rewilding Europe, Wouter Helmer, explains that a combination of intensified land use in agriculture and urbanization, made a lot of marginal nature areas available as they have been abandoned. Rewilding is a planned activity and happens mostly on those areas where in the past, to a greater of lesser degree, human activity has taken place (Wolf, 2012, p.103). Human management, in the form of an initial reset and later iterations are thus not out of question. This new approach was proactive rather than reactive (p.105). It subscribed 
to the postmodern spirit of the time and considered the possibility of having a "nature experience" more important than the practical utility of nature (p.106).

In the Netherlands, one of the most densely populated countries in Europe, the approach to nature conservation which dominated up until 1990, has also been defensive; trying to protect and conserve the last remnants of natural values as known before 1850 , before the Netherlands underwent large-scale industrialization and urbanization and intensified land use (Feddes, 2012, p.11). "Nature was something to be managed like a farm" (Kolbert, 2012, p.52).

In 1990, the first Nature Policy Plan, a document in which the long-term nature policy of the government is put forward, was approved by the Dutch parliament. This turned out to be a pivotal document in that it presented a proactive rather than reactive strategy of conservation with as its primary goal to extend natural landscapes (Swart, Van Der Windt \& Keulartz, 2001, p.231). The Oostvaardersplassen is probably the best-known example of rewilding in the Netherlands. An overview of its history, provided in the following section will provide as the basis for the analyses of the narrative used to describe the Oostvaardersplassen project. Special attention will be paid to the moments of (radical) human intervention as these go against the narrative told about this new wilderness. Other soft aspects and developments will also be covered later in the analysis.

\section{The Oostvaardersplassen}

The ljsselmeer in the centre of the north of the Netherlands became a freshwater lake after it was separated from the Wadden Sea by the Barried Dam in 1932. Later, in 1968, Southern Flevoland was reclaimed from the sea. This province is the newest province of the Netherlands "a state that is partly administrative, partly existential" (Kolbert, 2012, p.50). The lowest part, initially destined to be an industry area, remained empty. By the end of the summer of 1968, a variety of animals had already found their way to the area. In its second year, due to a change in vegetation, a large group of geese had made the nature area its home. The natural values of the area, which progressed very rapidly, turned this area into an important wetland. Not much later, the first plans to turn this area into a nature reserve were drawn up as a group of biologists convinced the Dutch government of the value of the area. "In 1973, it was necessary to interfere in the advancing cultivation of the surrounding areas of the Oostvaardersplassen; on the basis of a first ecological analysis, preliminary boundaries were set in 1974 and the first conservation measures taken" (Wigbels, 1990, p.7). The area was demarcated and a pump was also installed to regulate the water levels in the reserve, an important factor in its maintenance. "The water management which was then started has greatly influenced the look and the 
characteristics of the Oostvaardersplassen" (p.8).

The fact that some animals settled in this area spontaneously made many people believe this area developed spontaneously, although the contrary is true. Interference, however, does not mean that the Oostvaardersplassen as new wilderness immediately loses its naturalness as it can be argued that "nature 'only' responds to that which is offered" (p.9), it is not intrinsically changed by the interventions. Another human interference, however, could not be avoided; the train track, originally destined to run through the centre of the reserve, had to move to the outer part of the area because it could possibly kill or hurt birds which would fly against the trains or their electricity wires. The area around the Oostvaardersplassen was also redesigned as it was important, according to some ecologists, that the reserve itself was bordered by a dry area of roughly the same size (p.10).

A special commission, the Management Commission Oostvaardersplassen, was made responsible for the area. A group of experts previously active for a number of different conservation organizations had to now work closely together and make their beliefs somehow align. The first report they published in 1987 was a compromise according to Frans Vera (Vera, personal communication, June 3, 2014). "The most important problem which the management of a flat lowland march such as the Oostvaardersplassen poses is the simultaneous preservation of its diversity and dynamism" (p.13). As a solution to this problem, the area was divided into small sections each with its own water level; very intensive human intervention indeed. The Greylag Goose grazing in the area is by some, like Frans Vera, considered a gift as it maintains the area by itself. Others however, believe the geese mainly damage the area as some breeding birds do not return to the Oostvaardersplassen because the vegetation which changed due to the geese grazing does not appeal to them. These breeding birds still find other places in natures reserves just outside the Oostvaardersplassen to breed (Vera, personal communication, June 3 , 2014).

In the context of rewilding, this area became interesting as it offered the opportunity of returning to a Paleolithic landscape. In order to do that, Frans Vera, among others, stocked the reserve with large grazers who would play a key role in its further maintenance. Proxies had to be used for the animals who are, by now, already extinct. Heck cattle, was introduced to stand-in for the extinct auroch bovine. Konick horses were imported from Poland and red deer were shipped in from Scotland. "Like genuinely wild animals, these in the Oostvaardersplassen are expected to fend for themselves. They are not fed of bred or vaccinated" (Kolbert, 2012, p.55). A large number of animals die every winter due to a lack of food available. This causes a lot of public and political disputes. According to 
Frans Vera, however, death is an intrinsic part of wilderness, and any measure taken to assist the animals, like the practice of reactive culling, according to him has more to do with protecting the feelings of humans rather than with animal welfare (Vera, personal communication, June 3, 2014). After a court case in 2007, in which the Dutch Animal Welfare Association asked for more clarity about the animals in the area which, according to them, were not cared for properly, the court determined that the animals in the area do receive the necessary care. Staatsbosbeheer did, however, decide that they would implement reactive culling to limit animal suffering (Vera, personal communication, June 3, 2014; Drenthen, personal communication, June 3, 2014).

\section{Analysis}

The narrative of the Oostvaardersplassen presented by the experts in their publications, the film about the nature reserve as well as the book and the educational material published in the aftermath of the film highlights certain aspects of its history while it shades others. This is done consciously to either avoid criticism or promote a certain agenda, in this case, rewilding.

Especially the role of experts in the establishment as well as maintenance of this new wilderness is downplayed. This is, in most cases, done by advancing nature, or natural processes rather, as the protagonist of the narrative (Vera \& Sietsma, 2013, p.10). The reserve is described as a place where one can see how animals and plants behave without our interference (p.10). Nature does it on its own ${ }^{3}$ is the title of one of the chapters of the book EMS Films published with the release of their full-feature film about the area. A nature area reserve like the Oostvaardersplassen, they claim in this chapter, can simply not be managed. Intervention is not needed as nature "does it on its own" (p. 66). Although it is true that natural processes played a key role in the establishment of new wilderness in the reserve, the experts provided some of the basic elements necessary for these natural processes to occur and, especially in the first couple of years, played a big role in managing the reserve. Nature alone did not re-create wilderness. The history of the Oostvaardersplassen project, as I have described above, is one of human intention and intervention. Through the various stages of re-claiming the land, (first from the sea, and later from its original fate as an industrial area), moving the railway and stocking the reserve with animals which would function as the 'architects' of the reserve, as well as establishing other parameters for the creation of new wilderness, human interventions have played a key role in making this nature reserve possible. 
The agency of animals is also stressed in justifying new wilderness and all its artificial aspects. Frans Vera, when interviewed for an essay in The New Yorker for example, said: "So, this is the ultimate proof. There's no bird here who says, 'I won't breed here, because it is unnatural - it's four and a half meters below sea level, and I never did that' " (Vera as quoted in Kolbert, 2012, p.55). Later in the same interview he tells about a particular type of rare eagle, which would, according to other experts, only nest in very tall trees. The eagle did, however, show in up in 2006 and build its nest in a very small tree. Both the film De Nieuwe Wildernis as well as the book with the same title are full of these kinds of anecdotes which grant agency to certain animals, who to most, seem to act out of instinct rather than purpose. It is a form of animism used to attribute meaning to the actions of animals.

The animals in the reserve, especially the large grazers, did not arrive on their own and were consciously chosen for their function as well as to fit a certain image of wilderness the Polish konick horses for example, which are believed to be the descendant of tarpans, one of the world's last truly wild horse species (Vera \& Sietsma, 2013, p.17). These horses are, nevertheless, not really wild as they are the offspring of domesticated hoses that were at some point released into the wild again. They do look like wild horses, but they could also have picked Icelandic horses, or other horses that can resist harsh winter conditions (Drenthen, personal communication, May 12, 2014; Kolbert, 2012, p.52). Choosing large grazers that look less like wild animals and more like our domesticated cattle and horses would, however, quite possibly give rise to a debate on the reason for existence of the area, according the environmental philosopher Martin Drenthen. According to him, it would only take a week before farmers would start to complain and want to use the area as agricultural land again (Drenthen, personal communication, May 12, 2014). The way the chosen animals look is thus a vital part of the scripting. They literally play a role. Same goes for the Heck cattle. They have an even more interesting background, as they were purposely bread by two German brothers in the 1920 s who decided to breed back this lost species "using genetic material that had been preserved in domesticated cattle" (Kolbert, 2012, p.56). Inspired by old images of this species they crossbred cattle from different zoos. Heck cattle, one could argue, is less natural then a lot of other types of cattle they could have chosen.

The Oostvaardersplassen are coded as an area in which animals are free to do whatever they want. This is true in so far as this is possible. Especially the fence around the area taints the script of the autonomy of the wildlife. The fence around the area, in combination with the high number of animals dying during winter has made people compare Frans Vera to Hitler and the Oostvaardersplassen to a concentration camp (Hopster, 2005: 
Kolbert, 2013, p 51). Frans Vera, however, explains the fence positively, as a means to keep us people out, rather than to lock the animals in. It is there, he claims, to create space (Vera, personal communication, June 3, 2014). A similar strategy is used when the experts are confronted with questions about the presence of the railway, highways, high-voltage power lines and other unnatural objects in the reserve. These, according to both Helmer and Vera, don't detract from experiencing the nature reserve as wilderness but rather add to the experience as they prove that even next to these ugly human artifices wilderness can hold its own (ibid; Helmer, personal communication, June 3, 2014). The film about the Oostvaardersplassen had chosen a different tactic however.

De Nieuwe Wildernis (2013), the first Dutch feature-length wilderness film ever made, premiered on September 26th, 2013. It shows animal life in the Oostvaardersplassen during four seasons, based on two years of filming in the nature reserve. The result of this effort is a film, as the makers of it want us to call it - rather than a documentary, which can easily compete with the acclaimed documentary Planet Earth produced by the BBC (2006). The fact that the directors see this documentation as a film says something about what they want to show. It was their aim to capture the circle of life in the Oostvaardersplassen. It shows the affluence of spring and summer, and it shows how only the strongest survive when the landscape turns cold and sober in winter, and food is scarce (Verkerk \& Smit, 2013). To some extent, the film definitely does just that. Nobody would deny, however, that this film heavily relies on the received wilderness idea to present the Oostvaardersplassen as, in their words: "Dutch nature like you have never seen it before."

In doing this, the film-makers have chosen to script the Oostvaardersplassen differently. They do not emphasise the post-modern aspects of a re-wilding effort which has given us a new wilderness located only an hour and a half away from the capital of the Netherlands. The film rather leaves out these aspects. They have skillfully and ingeniously been able to keep the very human objects, like the trains, cars, boats, high-voltage power lines, you would encounter while being in the area, out of the frame. The film makes no reference to the cities around the nature reserve at all. There is only one moment in which two ice-skaters skate by, briefly, in the distance. All human interventions needed to keep the Oostvaardersplassen 'on its feet' are never mentioned either, not even a park ranger. This gives the impression that the nature reserve is a lot bigger than it actually is. It also makes the audience forget that there is a fence around this area. It zooms in on those aspects of the Oostvaardersplassen, which are natural, and ignores the artificial ones. The film was so successful in its scripting that in the weekend after the film premiered, more than 1500 people came to see it with their own eyes, an increase of about 150 percent compared to the same day the year before. 
Sometimes, even the choice for a certain intervention shows a sign of being scripted. The practice of culling for example does not seem appropriate in a wilderness reserve. In the Oostvaardersplassen, however, the practice is described as 'early reactive culling' which means that the forest ranger or hunter will wait with culling until the animal itself clearly shows that it is going to die; only then are they allowed to be shot. The carcasses are left in the area as they serve a purpose in this wilderness area as foods for animals of prey (Natural processes, animal welfare, moral aspects and management of the Oostvaardersplassen, 2010, pp.8-10). This case clearly shows that that basic idea of nature leading the way is dominant in the approach but executed in such a way that the experts can still justify their interventions.

A last issue worth discussing is the idea of the reset. The Oostvaardersplassen regularly need a reboot. The area has to be flooded with water once in a while as this would naturally happen if there were no dykes to keep the water out. Those resets needed to allow ancient ecosystems to reassert themselves are paradoxical Drenthen explains, as they are inspired by natural events that would possibly happen if there were no dykes, but at the same time, in practice, ask for practical expert intervention (Drenthen, personal communication, May 12, 2014). This explanation of a natural process, justified by the script that it is something which would naturally occur, is paradoxical because it would never have occurred where the Oostvaardersplassen are located, as this area used to be completely and permanently under water. This is,f thus, yet another example of the work necessary to make the Oostvaardersplassen wilderness, justified by a script.

\section{Discussion}

This study set out to answer the question what role experts play in establishing and maintaining the Oostvaardersplassen as new wilderness, both physically as well as mentally. The Oostvaardersplassen served as a case study as experts had to not only establish physical wilderness here, but also make people understand the product of their labor as such; real wilderness worth conserving. The experts associated with the Oostvaardersplassen project have scripted the landscape, in their publications, the film about the nature reserve, as well as in their the practical undertaking, in such a way that it can be understood as some new form of pristine wilderness. Even the biggest violations of this concept, like for example the railway lines at the edge of the reserve are translated into circumstances that only underline the wildness rather than diminish it. The Oostvaardersplassen can thus be said to be both artificial and hyper-natural at the same time, a product of post-modern thinking about conservation and the concept of wilderness in general. It is the outcome of a changing philosophy in nature conservation 
towards nature development, the precursor to the rewilding movement, a hands-off approach in which nature is said to lead the way. Rewilding offers a solution to the problem of the lack of real wilderness, as understood as pristine and untrammeled, in the Netherlands, as it allows for intervention. It sees the value of nature not in that which exists, but that which returns after we have destroyed it, almost completely. It sees wilderness as that which can remain dispute our presence. What has become apparent in the analysis is that, in scripting the Oostvaardersplassen, the experts still use the values associated with our received idea of wilderness to give their new wilderness meaning as this particular understanding of wilderness appeals to the masses and helps advance highly controversial projects like the Oostvaardersplassen.

The concept of scripted space helped decode this coded landscape and elucidate the way in which experts tell the story of the Oostvaardersplassen, and to what extent their story lines up with their actions. It also helped develop an alternative understanding of the reasons behind the controversy, or at least deepen our current understanding of it.

This study has made clear that what experts do and what experts say they do are sometimes two different things. The concept of scripted space in combination with an understanding of the deconstruction of the concept of wilderness will now offer a tool for analysing any future debate on the meaning of new wilderness in the Netherlands. Even for the experts themselves this insight might offer a way of analysing their own practices and whether they align with their core beliefs about wilderness. It also allows experts with different opinions on the matter to have a meaningful discussion, as they are now able to separate meaning from practice.

\section{Conclusion}

The Oostvaardersplassen are a new wilderness. New, because it is a Genesis-like creation on a piece of land, which lay at the bottom of an inlet of the North Sea for most of the past several millennia; wild as it is said to let nature lead. That statement refers to a time before man became a dominant factor on earth. A Paleolithic landscape without man-made barriers and/or obstacles - not the baseline of half-nature from around 1850 traditionally used in nature conservation, but - pristine and untrammeled, wilderness. In order to create such a landscape an initial reset and possible periodic intervention are needed. These mediations by humans, however, do not fit in our received idea or understanding of wilderness as pure and untouched, as wilderness is classically defined by the absence of humans. The biggest obstacle for the experts associated with the Oostvaardersplassen is the amount of work, both physically as well as mentally, that is needed to disguise new wilderness as pristine wilderness. But what about the received idea of wilderness is so 
desirable? What does it offer? What the analysis has shown is that representing new wilderness as pristine helps advance rewilding as a new conservation practice. This is needed as rewilding is based on a new paradigm, which acknowledges that untouched wilderness no longer exists in the Netherlands and allows for intervention to re-create such wildernesses; a paradigm which is not yet completely accepted.

What also becomes clear from the analysis is that the difficulty is that the scripting of new wilderness, as carrying those same values associated with the received idea of wilderness, does not convince everybody, as that image is affected by the physical actions needed to get to a situation where the physical and the mental story would be more analogous. This contradiction between the discourse and practice of the experts is the actual source of the controversy. If discourse and practice would align and no human being would even enter the nature reserve, the fact that animals die of starvation would be less of an issue. The fact that a park ranger and a veterinarian cross the Oostvaardersplassen daily to make sure everything is alright, for some people, turns the Oostvaardersplassen into a zoo.

Although it is not hard for people to understand that real untouched wilderness areas not longer exist, it is a bit harder to see how rewilding projects equate the meaning of new wilderness to that of the pristine and untouched wilderness we can never get back. Does the Oostvaardersplassen project even make sense, remains the dominant question however, if it is seemingly so difficult to create what ought to be automatic, free and wild?

\section{References}

1. BBC (2013). Environmentalist George Monbiot on 'rewilding' Britain. [Video]. Great Britain: BBC. Retrieved from $h t t p: / / w w w . b b c . c o . u k / n e w s / u k-22706729$

2. Berg, van den, A. (1999). Individual Differences in the Aesthetic Evaluation of Natural Landscapes. PhD thesis, University of Groningen, Groningen.

3. Callicott, J. B., \& Nelson, M. P. (1998). The Great New Wilderness Debate. Athens, GA: The University of Georgia Press.

4. Carluccio, T. \& Bloom, I.M. (2012). Judge grants 120-day reprieve for PA municipalities; Bucks County forum. Retrieved from http://protectingourwaters.wordpress.com/2012/04/12/judge-grants-12O-day-reprievefor-pa-municipalities-bucks-county-forum/ on 13 June 2014

5. Cronon, W. (1995). The Trouble with Wilderness; or, Getting Back to the Wrong Nature. Uncommon Ground: Toward Reinventing Nature. 69-90. New York: Norton.

6. Drenthen, M. (2003). Grenzen aan wildheid: wildernisverlangen en de betekenis van Nietzsches moraalkritiek voor de actuele milieu-ethiek. Budel: Uitgeverij Damon.

7. Drenthen, M. (2005). Wilderness as a Critical Border Concept: Nietzsche and the Debate on Wilderness 
Restoration. Environmental Values 14. 317-337.

8. Feddes, F (2012). De ecologische hoofdstructuur voorbij. In Freddes, Y. (Eds.). Voorbij de EHS Koers voor het nieuwe natuurbeleid. Den Haag: College van Rijksadviseurs.

9. Gorter, H.P. (1986), Ruimte voor natuur. s-Graveland: Natuurmonumenten.

10. Helmer, W. (2014, June 3). Personal interview.

11. Hertz, R., \& Burton, P. (1996). The Language of Scripted Spaces. Landscape Review 2(3). 24-32.

12. Hopster, H. (2005, September 3). De Oostvaardersplassen: een concentratiekamp? Paarden zijn toch geen koolmezen. Retrieved from http://www.nrc.nl/handelsblad/van/2005/september/o3/de-oostvaardersplasseneen-concentratiekamp-paarden-10620666

13. Klein, N. M. (2004). The Vatican to Vegas: A History of Special Effects. New York, NY: The New Press.

14. Kolbert, E. (2012, December). Recall of the Wild: The Question to Engineer a World Before Humans. The New Yorker, 50-60.

15. Nash, R. (2001). Wilderness and the American Mind. New Haven, CT: Yale University Press

16. Navarro, L. M., \& Pereira H. M. (2012). Rewilding Abandoned Landscapes in Europe. Ecosystems 15, 900-912.

17. MacArthur, R., \& Wilson, E. O. (1967). The Theory of Island Biogeography. Princeton, NY: Princeton University press.

18. MacKinnon, J. B. (2013) The Once and Future World: Nature as it was, as it is, as it could be. Toronto: Random House Canada.

19. Slobbe van, T. (2005). Dagboek van een Lege Plek. Beek-Ubbergen, NL: Stichting wAarde.

20. Swart J.A.A., H.J. van der Windt \& J. Keulartz (2001) 'Valuation of nature in conservation and restoration'. Restoration Ecology, 9 (2): 230-238

21. Vera, F. (1979). Het Oostvaardersplassengebied: Uniek oecologisch experiment. Natuur en Milieu. 79(3) 3-12.

22. Vera, F., \& Sietsma, M. (2013). Oostvaardersplassen, De Nieuwe Wilderness: Grote Natuure in een Klein Land. Amsterdam: EMS Films

23. Vera, F. (2014, June 3). Personal interview.

24. Verkerk, M., \& Smit, R. (Directors). (2013). EMS Films: De Nieuwe Wildernis [Feature Film]. The Netherlands.

25. Vinegar, A., \& Golec, J. M. (2009). Relearning from Las Vegas. Minneapolis, MN: University of Minnesota Press.

26. Wigbels, V. L. (1990). Wetland Management in the Oostvaardersplassen. Den Haag: Ministerie van Verkeer en Waterstaat.

27. Windt, van der, H. (1995) Natuurbescherming in Nederland in de periode 1880-1990. Meppel/Amsterdam: Boom

28. Wolf, J. A. (2012). Wildernis in Nederland: Tussen Droom en Werkelijkheid. Groningen: Rijksuniversiteit Groningen. 